\title{
Respiratory symptoms and pulmonary functions before and after pesticide application in cotton farming
}

\author{
Zafer Hasan Ali SAK ${ }^{1, A-F} \oplus$, Şerif Kurtuluş ${ }^{1, A-F} \oplus$, Birsen OCAKLI ${ }^{2, A-F} \oplus$, Zehra Nur TÖREYINN ${ }^{3, B-C}$, \\ İbrahim BAYHAN ${ }^{4, B-C}$, M.İrfan YEŞiLNACAR ${ }^{4, B-C}$, Metin AKGÜN ${ }^{5, A-F}{ }^{\text {, Peri ARBAK }}{ }^{6, A-F} \odot$ \\ ${ }^{1}$ Department of Chest Diseases, University School of Medicine, Harran, Turkey \\ ${ }^{2}$ Chest Diseases and Thoracic Surgery Training and Research, Süreyyapaşa, Turkey \\ ${ }^{3}$ Department of Occupational Health and Occupational Diseases, University School of Medicine, Ege, Turkey \\ ${ }^{4}$ Department of Environmental Engineering, Harran University, Engineering Faculty, Turkey \\ ${ }^{5}$ Department of ChestDiseases, Atatürk University School of Medicine, Erzurum, Turkey \\ ${ }^{6}$ Department of ChestDiseases, University School of Medicine, Düzce, Turkey \\ A - Research concept and design, B - Collection and/or assembly of data, C - Data analysis and interpretation, \\ $D$ - Writing the article, E - Critical revision of the article, F - Final approval of article
}

Zafer Hasan Ali Sak, Şerif Kurtuluş, Birsen Ocakli, Zehra Nur Töreyin, İbrahim Bayhan, M.İrfan Yeşilnacar, Metin Akgün, Peri Arbak. Respiratory symptoms and pulmonary functions before and after pesticide application in cotton farming. Ann Agric Environ Med. $2018 ; 25(4)$ : 701-707. doi: $10.26444 / a a e m / 99561$

\begin{abstract}
Ojective. To investigate respiratory health problems related to pesticide exposure in the inhabitants of agricultural areas. Materials and method. This study included 252 participants prior to pesticide application and 66 participants from the first group after pesticide application across four cotton farms. Symptom questionnaires were filled out by participants and respiratory function tests were measured before and after pesticide exposure. In addition, $\mathrm{PM}_{10}, \mathrm{PM}_{2.5}$, air temperature, and humidity were measured in all four farming villages before and after pesticide administration.

Results. $\mathrm{PM}_{10}$ and $\mathrm{PM}_{2.5}$ levels were significantly increased after pesticide application. After pesticide application, all participants' nose, throat, eye, and respiratory complaints increased significantly. Expected forced vital capacity (FVC) and forced expiratory volume in one second $\left(\mathrm{FEV}_{1}\right)$ percentage values decreased significantly. The rates of FVC and FEV values $^{2}$ lower than $80 \%$ were $23.5 \%$ and $22 \%$, respectively, before pesticide application, and this rate increased to $42.4 \%$ and $43.1 \%$, respectively, after pesticide application. There was a significant negative correlation between $\mathrm{PM}_{10}$ levels and FVC, FEV $_{1}$, and PEF values. After $\mathrm{PM}_{2.5}$ pesticide application, the risk of experiencing burning in the mouth, nose, and throat increased by 2.3-fold (OR: 2.316), 2.6-fold for burning symptoms in the eyes (OR: 2.593), 2.1-fold for wheezing (OR: 2.153), and 2.2-fold for chest tightness (OR: 2.211). With increased PM 10 levels, the risk of chest tightness increased 1.1-fold (OR: 1.123).

Conclusions. After pesticide administration, the respiratory health of the participants deteriorated. Performing pesticide applications in agriculture with harmless methods is the most important measure to be taken to protect public health
\end{abstract}

Key words

pesticides, $\mathrm{PM}_{10}, \mathrm{PM}_{2.5}$, pulmonary functions, respiratory symptoms

\section{INTRODUCTION}

It is known that the pollution of particulate matter $(\mathrm{PM})$ in cities and regions of concentrated industry is increasing. Particulate matter is a mixture of solid, liquid, organic, and inorganic substances. PM can remain in the atmosphere for 3-10 days, depending on environmental conditions. Under certain meteorological conditions, PM can also be transported thousands of kilometers away. Investigations have shown that agricultural activities also lead to considerable PM pollution [1]. PM-producing agricultural activities include soil cultivation, preparation for dibbling, sowing, application of fertilizers and pesticides, crop harvesting, and post-harvesting processes. Land preparation and harvesting activities in California can produce different levels of $\mathrm{PM}_{10}$, and the levels of $\mathrm{PM}_{10}$ can be decreased [2]. Agricultural activities in the European Union countries are responsible for $5 \%$ of all $\mathrm{PM}_{2.5}$ production and $25 \%$ of

Address for correspondence: Zafer Hasan Ali SAK Department of Chest Diseases, Harran University School of Medicine, osmanbey campus, 63300 Sanliurfa, Turkey e-mail: drsak19@gmail.com

Received: 14.05.2018; accepted: 04.11.2018; first published: 05.12.2018
$\mathrm{PM}_{10}$ production [3]. In a study conducted by Bogman et al. [4], agricultural activities accounted for $24 \%$ of all $\mathrm{PM}_{10}$ production.

Pesticide application increases the density of PM substances in agricultural processes, and chemically active particles are transported to areas far from the application area by wind, and through inhalation also affect people living around the application area $[5,6,7]$. Pesticides are bioactive compounds used to eliminate pests and to protect crops from them. When pesticides are used intensively, they are found not only in soil, water, and crops, but also in the atmosphere. Particularly semi-volatile pesticides are commonly found in both gas and particulate form in the atmosphere [8].

The effects of pesticides on the respiratory system were explored in detail in a community working in a plant that mixes organophosphates and carbamates with alkalis. Acute findings in the employees included dyspnea, eye irritation, dryness in the nose, and occasional nasal discharge. Chronic cough, dyspnea, and nasal discharge are even more frequent findings in employees chronically exposed to pesticides. The $\mathrm{FVC}, \mathrm{FEF}_{25}$, and $\mathrm{FEF}_{50}$ values of the employees were found to be lower than the expected values [9]. 
While discussing the adverse health effects of $\mathrm{PM}_{10}$ and $\mathrm{PM}_{2.5}$ production associated with pesticide use in agricultural areas, it is advisable to assess both the health effects associated with particulate matter and the pesticide-related impact. This study aimed to investigate the effect of pesticide application on particulate matter exchange in cotton agriculture and the level of influence of such application on symptoms and pulmonary function tests.

\section{MATERIALS AND METHOD}

Subjects. The study was conducted between June - August of 2016 in the Harran province of Urfa City, a cotton-producing city located in the southeastern part of Turkey. The cotton planting period in the region is from 20 April - 15 May. The first watering in cotton cultivation takes place 40-45 days after planting, and the last watering takes place in the last week of August or the first week of September at the latest. According to this schedule, the cotton is irrigated 11 times in total, three times in June at 10-day intervals and four times in July and August at eight-day intervals. Irrigation is performed nine times at 10-day intervals during seasons in which water is scarce. The pesticide included a mixture of Lambda-Cyhalothrin (7 g/da), Emamectin benzoate (4 g/da) and Nitrogen $(40 \mathrm{~g} / \mathrm{da})$, phosphorus pentaoxide $(200 \mathrm{~g} / \mathrm{da})$, and zinc $(120 \mathrm{~g} / \mathrm{da})$ is applied to kill green worms (Helicover paarmigera), which are harmful to cotton plants. Pesticide application for green worms is usually carried out at the end of June, from July 15-25, and during mid-August. A total of 252 volunteers living in four farming villages (Giyimli, Küçük Minareli, Büyük Minareli, and Bozyaka) spread over $65 \mathrm{~km} 2$ were evaluated before the application of pesticides (midJune). After pesticide application (mid-August), 66 people from the first group agreed to participate in a reevaluation of their health. Ethical approval for this study was given by the Ethics Committee of Harran University.

Symptoms. Individuals were asked about the presence of symptoms, such as nose and throat burning or stinging; eyes burning, stinging, or watering; coughing; phlegm; wheezing; and a feeling of chest tightness before and after pesticide application. Symptom data was collected with a standard questionnaire.

Spirometry. Individuals were subjected to respiratory function tests (MIR SpiroLab 3 Spirometer) in indoor settings (village rooms, schools, and headman rooms) before and after pesticide application. Spirometric measurements were performed by four people in a sitting position (ZS, SH, PA, BO). At least three times, technically acceptable, forced vital capacity maneuvers were performed, and the highest spirogram was recorded. Spirometric values were expressed as a percentage of the expected value. The forced vital capacity (FVC), forced expiratory volume in one second $\left(\mathrm{FEV}_{1}\right)$, $\mathrm{FEV}_{1} / \mathrm{FVC}$ and maximum mid-expiratory flow rate (MMFR) were assessed before and after the application of the pesticide.

Dust measurement. $\mathrm{PM}_{10}$ is defined as particles with a diameter of $10 \mu \mathrm{m}$ or less, and $\mathrm{PM}_{2.5}$ is defined as those with a diameter of $2.5 \mu \mathrm{m}$ or less. A calibrated pDR 1500 (Thermo Scientific Personal Data RAM pDR) device and two calibrated cyclones were used to make $\mathrm{PM}_{10}$ and $\mathrm{PM}_{2.5}$ measurements in the environment. Device calibration was performed before each sampling. Before starting sampling, the coordinates and altitude of the working area were determined by a Magellan GPS device. Fifteen-minute measurements of $\mathrm{PM}_{10}$ and $\mathrm{PM}_{2.5}$ were made with the cyclones. Measurements were made at the four village centers (in four villages spread over $65 \mathrm{~km} 2$ ) before agricultural spraying (in mid-June) and within 15 minutes and 48 hours after agricultural spraying (in mid-August).

Statistical data. Analyzed using the Statistical Package for Social Sciences (SPSS) software version 21.0 (SPSS Inc., Chicago, IL).An independent-samples t-test was used to compare independent groups, whereas a paired samples t-test was used to compare dependent groups. A repeated ANOVA test was used for multiple comparisons. The distribution of categorical variables in both groups was compared using Pearson's chi-square test. Data are expressed as the mean \pm standard deviation (SD). Categorical variables are expressed as frequencies and percentages. Statistical significance was assumed at $\mathrm{p}<0.05$. A Wilcoxon test was used to compare mean $\mathrm{PM}_{10}, \mathrm{PM}_{2.5}$, heat, and humidity levels obtained before and after pesticide applications. A McNemar test was used to compare paired proportions before and after pesticide applications. Linear regression was used to investigate the relationships among participant respiratory functions, gender, smoking history, and levels of $\mathrm{PM}_{10}$ and $\mathrm{PM}_{25}$. Odds ratios were calculated using a logistic regression analysis for each respiratory and eye, nose, and throat symptom (age, gender, smoking status and levels of $\mathrm{PM}_{2.5}$ and $\mathrm{PM}_{10}$ after pesticide application were the predictors).

\section{RESULTS}

The study included 252 subjects (108 males [42.9\%] and 144 females [57.1\%]) before pesticide application and 66 (30 males [54.5\%] and 36 females [45.5\%]) after pesticide application, with an average age of 42.3 and 42.3 before and after pesticide application, respectively. Characteristics of the individuals participating in the study are shown in Table 1.

The mean duration of exposure of individuals to pesticides was $15.2 \pm 2.7$ (range: $1-53$ ) years.

The frequency of symptoms that occurred during the previous pesticide-spraying period is given in Table 2. Among the five most frequently observed symptoms due to pesticide application were eye burning, dyspnea, headache, cough, and itching. $\mathrm{PM}_{10}, \mathrm{PM}_{2.5}$, and average values of temperature and humidity measured in the village before and after pesticide application-are shown in Table 3. The frequency of symptoms affecting the mouth, nose, throat, eyes, and respiratory system before and after spraying and pulmonary function tests before and after pesticide application are provided in Table 4.

After pesticide application, all nose, throat, eye, and respiratory symptoms increased significantly and expected $\mathrm{FVC}$ and $\mathrm{FEV}_{1}$ percentage values decreased significantly. The rates of FVC and $\mathrm{FEV}_{1}$ values lower than $80 \%$ were $23.5 \%$ and $22 \%$, respectively, before pesticide application, and these rates increased to $42.4 \%$ and $43.1 \%$, respectively, after pesticide application.

The proportion of those with $\mathrm{FEV}_{1} / \mathrm{FVC}$ below $70 \%$ fell from $5.3 \%$ to $1.5 \%$. The percentage of MMFRs expected to be less than $65 \%$ percent increased from $29.1 \%$ to $37.1 \%$. 
Table 1. Characteristics of study subjects

\begin{tabular}{|c|c|c|c|c|}
\hline & $\begin{array}{c}\text { Before } \\
\text { pesticide } \\
n=252\end{array}$ & $\begin{array}{c}\text { Before } \\
\text { pesticide } \\
\%\end{array}$ & $\begin{array}{c}\text { After } \\
\text { pesticide } \\
n=66\end{array}$ & $\begin{array}{c}\text { After } \\
\text { pesticide } \\
\%\end{array}$ \\
\hline \multicolumn{5}{|l|}{ Gender } \\
\hline Male & 108 & 42.9 & 30 & 54.5 \\
\hline Female & 144 & 57.1 & 36 & 45.5 \\
\hline \multicolumn{5}{|l|}{ Smoking } \\
\hline Yes & 123 & 48.8 & 31 & 47.0 \\
\hline No & 129 & 51.2 & 35 & 53.0 \\
\hline \multicolumn{5}{|l|}{ Villages } \\
\hline Giyimli & 91 & 36.1 & 13 & 19.7 \\
\hline Küçük Minareli & 77 & 30.6 & 14 & 21.2 \\
\hline Büyük Minareli & 57 & 22.6 & 29 & 43.9 \\
\hline Bozyaka & 27 & 10.7 & 10 & 15.2 \\
\hline Graduate & $n=252$ & $\%$ & $n=63$ & $\%$ \\
\hline Illiterate & 98 & 38.9 & 27 & 42.9 \\
\hline Primary school & 90 & 36.1 & 18 & 28.6 \\
\hline Higher education & 64 & 25.0 & 18 & 28.5 \\
\hline \multicolumn{5}{|l|}{ Previous diseases } \\
\hline None & 143 & 56.7 & 41 & 62.1 \\
\hline Cardiovascular & 25 & 9.9 & 7 & 10.6 \\
\hline COPD & 14 & 5.6 & 5 & 7.6 \\
\hline Asthma & 11 & 4.4 & 2 & 3.0 \\
\hline Other & 59 & 23.4 & 11 & 16.7 \\
\hline
\end{tabular}

Table 2. Symptoms of individuals during previous pesticide spraying periods

\begin{tabular}{lcc}
\hline & No. of subjects & Percent (\%) \\
\hline Eye burning & 114 & 45.2 \\
\hline Dyspnea & 95 & 37.7 \\
\hline Headache & 79 & 31.3 \\
\hline Cough & 77 & 30.6 \\
\hline Itching & 68 & 27.0 \\
\hline Weakness & 62 & 24.6 \\
\hline Fatigue & 55 & 21.8 \\
\hline Nausea & 46 & 18.3 \\
\hline Blurred vision & 42 & 16.7 \\
\hline Inappetency & 36 & 14.3 \\
\hline Drowsiness & 33 & 13.1 \\
\hline Muscle-joint pain & 32 & 12.7 \\
\hline
\end{tabular}

Table 3. Mean values of $\mathrm{PM}_{10}, \mathrm{PM}_{2,5^{\prime}}$ temperature and humidity in the villages before and after pesticide application

\begin{tabular}{|c|c|c|c|}
\hline & \multicolumn{2}{|c|}{ Mean } & \multirow[b]{2}{*}{$\mathrm{P}$} \\
\hline & Before pesticide & After pesticide & \\
\hline \multicolumn{4}{|l|}{$\mathrm{PM}_{10}$} \\
\hline Giyimli & 11.7 & 334.8 & $<0.001$ \\
\hline Küçük Minareli & 20.2 & 328.2 & 0.001 \\
\hline Büyük Minareli & 27.8 & 313.5 & $<0.001$ \\
\hline Bozyaka & 23.8 & 319.3 & $<0.001$ \\
\hline \multicolumn{4}{|l|}{$\mathrm{PM}_{2.5}$} \\
\hline Giyimli & 4.7 & 13.2 & $<0.001$ \\
\hline Küçük Minareli & 5.2 & 11.4 & 0.001 \\
\hline Büyük Minareli & 8.2 & 15.0 & $<0.001$ \\
\hline Bozyaka & 12.2 & 17.2 & $<0.001$ \\
\hline \multicolumn{4}{|l|}{ Heat } \\
\hline Giyimli & 32.1 & 37.8 & $<0.001$ \\
\hline Küçük Minareli & 31.8 & 36.7 & $<0.001$ \\
\hline Büyük Minareli & 31.6 & 36.1 & $<0.001$ \\
\hline Bozyaka & 31.7 & 36.8 & $<0.001$ \\
\hline \multicolumn{4}{|l|}{ Humidity } \\
\hline Giyimli & 25.5 & 52.8 & $<0.001$ \\
\hline Küçük Minareli & 25.5 & 52.8 & 0.001 \\
\hline Büyük Minareli & 28.2 & 52.8 & $<0.001$ \\
\hline Bozyaka & 34.6 & 56.3 & 0.002 \\
\hline
\end{tabular}

Table 4. Pre-and post-spraying symptoms and pulmonary functions of the study group

\begin{tabular}{|c|c|c|c|c|c|}
\hline & \multicolumn{2}{|c|}{ Before pesticide $n=252$} & \multicolumn{2}{|c|}{ After pesticide $n=66$} & \multirow{2}{*}{$\mathrm{P}$} \\
\hline & $\mathrm{n}$ & $\%$ & $\mathrm{n}$ & $\%$ & \\
\hline $\begin{array}{l}\text { Mouth-nose-throat } \\
\text { burning }\end{array}$ & 24 & 9.5 & 47 & 71.2 & $<0.001$ \\
\hline Sneezing & 6 & 2.4 & 44 & 66.7 & $<0.001$ \\
\hline Eye burning & 30 & 11.9 & 51 & 77.3 & $<0.001$ \\
\hline Cough & 13 & 5.2 & 45 & 68.2 & $<0.001$ \\
\hline Phlegm & 10 & 4.0 & 43 & 65.2 & $<0.001$ \\
\hline Wheezing & 11 & 4.4 & 41 & 62.1 & $<0.001$ \\
\hline Dyspnea & 22 & 8.7 & 44 & 66.7 & $<0.001$ \\
\hline \multirow[t]{2}{*}{ Chest tightness } & 17 & 6.7 & 41 & 62.1 & $<0.001$ \\
\hline & \multicolumn{2}{|c|}{$\begin{array}{l}\text { Before pesticide } n=247 \\
\quad(\text { Mean, SD) }\end{array}$} & \multicolumn{2}{|c|}{$\begin{array}{l}\text { After pesticide } \mathrm{n}=66 \\
\quad(\text { Mean, SD) }\end{array}$} & $P$ \\
\hline FVC \% predicted & \multicolumn{2}{|c|}{$92.3 \pm 22.6$} & \multicolumn{2}{|c|}{$83.7 \pm 24.3$} & $<0.001$ \\
\hline $\mathrm{FEV}_{1} \%$ predicted & \multicolumn{2}{|c|}{$91.0 \pm 25.8$} & \multicolumn{2}{|c|}{$84.4 \pm 23.4$} & $<0.001$ \\
\hline $\mathrm{FEV}_{1} / \mathrm{FVC}$ & \multicolumn{2}{|c|}{$82.8 \pm 10.0$} & \multicolumn{2}{|c|}{$82.5 \pm 6.6$} & 0.168 \\
\hline MMFR \% predicted & \multicolumn{2}{|c|}{$78.8 \pm 28.5$} & \multicolumn{2}{|c|}{$78.0 \pm 30.8$} & 0.284 \\
\hline \multirow[t]{3}{*}{ PEFR \% predicted } & \multicolumn{2}{|c|}{$68.7 \pm 28.5$} & \multicolumn{2}{|c|}{$65.9 \pm 26.5$} & 0.185 \\
\hline & \multicolumn{2}{|c|}{ Before pesticide } & \multicolumn{2}{|c|}{ After pesticide } & \\
\hline & $\mathrm{n}$ & $\%$ & $\mathrm{n}$ & $\%$ & \\
\hline FVC $<80 \%$ predicted & 58 & 23.5 & 28 & 42.4 & $<0.001$ \\
\hline $\mathrm{FEV}_{1}<80 \%$ predicted & 54 & 22.0 & 28 & 43.1 & $<0.001$ \\
\hline $\mathrm{FEV}_{1} / \mathrm{FVC}<70 \%$ & 13 & 5.3 & 1 & 1.5 & 0.045 \\
\hline $\mathrm{FEV}_{1} / \mathrm{FVC}<75 \%$ & 27 & 10.9 & 1 & 1.5 & $>0.05$ \\
\hline MMFR $<65 \%$ & 71 & 29.1 & 23 & 37.1 & 0.001 \\
\hline
\end{tabular}


Table 5. Pre and post pesticide frequencies of health complaints and mean values of pulmonary functions of 66 subjects

\begin{tabular}{|c|c|c|c|c|c|}
\hline & \multicolumn{2}{|c|}{$\begin{array}{l}\text { Before pesticide } \\
\qquad n=66\end{array}$} & \multicolumn{2}{|c|}{$\begin{array}{l}\text { After pesticide } \\
\qquad n=66\end{array}$} & \multirow{2}{*}{$p$} \\
\hline & $\mathrm{n}$ & $\%$ & $\mathrm{n}$ & $\%$ & \\
\hline Mouth-nose-throat burning & 6 & 9.1 & 47 & 71.2 & $<0.001$ \\
\hline Sneezing & 2 & 3.0 & 44 & 66.7 & $<0.001$ \\
\hline Eye burning & 4 & 6.1 & 51 & 77.3 & $<0.001$ \\
\hline Cough & 2 & 3.0 & 45 & 68.2 & $<0.001$ \\
\hline Phlegm & 0 & 0.0 & 43 & 65.2 & $<0.001$ \\
\hline Wheezing & 2 & 3.0 & 41 & 62.1 & $<0.001$ \\
\hline Dyspnea & 6 & 9.1 & 44 & 66.7 & $<0.001$ \\
\hline \multirow[t]{2}{*}{ Chest tightness } & 3 & 4.5 & 41 & 62.1 & $<0.001$ \\
\hline & \multicolumn{2}{|c|}{$\begin{array}{c}\text { Before pesticide } \\
\quad n=66 \\
(\text { Mean, SD) }\end{array}$} & \multicolumn{2}{|c|}{$\begin{array}{l}\text { After pesticide } \\
\qquad \mathrm{n}=66 \\
(\text { Mean, SD) }\end{array}$} & $\mathrm{p}$ \\
\hline FVC $\%$ predicted & \multicolumn{2}{|c|}{$92.3 \pm 22.6$} & \multicolumn{2}{|c|}{$83.7 \pm 24.3$} & $<0.001$ \\
\hline $\mathrm{FEV}_{1} \%$ predicted & \multicolumn{2}{|c|}{$92.7 \pm 24.9$} & \multicolumn{2}{|c|}{$84.5 \pm 23.5$} & $<0.001$ \\
\hline $\mathrm{FEV}_{1} / \mathrm{FVC}$ & \multicolumn{2}{|c|}{$82.8 \pm 10.0$} & \multicolumn{2}{|c|}{$82.5 \pm 6.6$} & 0.768 \\
\hline MMFR $\%$ predicted & \multicolumn{2}{|c|}{$78.8 \pm 28.5$} & \multicolumn{2}{|c|}{$78.0 \pm 30.8$} & 0.786 \\
\hline \multirow[t]{3}{*}{ PEFR \% predicted } & \multicolumn{2}{|c|}{$68.7 \pm 28.5$} & \multicolumn{2}{|c|}{$65.9 \pm 26.5$} & 0.185 \\
\hline & \multicolumn{2}{|c|}{ Before pesticide } & \multicolumn{2}{|c|}{ After pesticide } & \\
\hline & $\mathrm{n}$ & $\%$ & $\mathrm{n}$ & $\%$ & T \\
\hline FVC $<80 \%$ predicted & 14 & 21.2 & 26 & 39.4 & 0.003 \\
\hline $\mathrm{FEV}_{1}<80 \%$ predicted & 15 & 22.7 & 28 & 42.4 & 0.002 \\
\hline $\mathrm{FEV}_{1} / \mathrm{FVC}<70 \%$ & 3 & 4.5 & 1 & 1.5 & 0.157 \\
\hline $\mathrm{FEV}_{1} / \mathrm{FVC}<75 \%$ & 7 & 10.8 & 1 & 1.5 & 0.014 \\
\hline MMFR $<65 \%$ & 17 & 26.6 & 23 & 35.9 & 0.109 \\
\hline
\end{tabular}

Table 6. Analysis of correlation between respiratory functions and age, smoking, $\mathrm{PM}_{10^{\prime}} \mathrm{PM}_{2.5}$ levels and distance to the field of pesticide application

\begin{tabular}{lccccc}
\hline & FVC & FEV1 & FEV1/FVC & PEF & MMFR \\
Age & & & & & \\
\hline $\mathrm{R}$ & -.425 & -.441 & -.337 & -.361 & -.466 \\
$\mathrm{P}$ & $<0.001$ & $<0.001$ & 0.006 & 0.003 & $<0.001$ \\
\hline
\end{tabular}

Smoking

duration

\begin{tabular}{llllll}
\hline$R$ & -.433 & -.472 & -.243 & -.254 & -.518 \\
$P$ & 0.008 & 0.004 & 0.154 & 0.141 & 0.001 \\
\hline
\end{tabular}

\begin{tabular}{lccccc}
$\mathrm{PM}_{10}$ & \multicolumn{5}{l}{} \\
\hline $\mathrm{R}$ & -.586 & -.473 & .154 & -.413 & -.214 \\
$\mathrm{P}$ & $<0.001$ & $<0.001$ & 0.225 & 0.001 & 0.089 \\
\hline
\end{tabular}

$\mathrm{PM}_{2.5}$

\begin{tabular}{lccccc}
\hline $\mathrm{R}$ & .322 & .224 & -.156 & .135 & -.039 \\
$\mathrm{P}$ & 0.009 & 0.075 & 0.219 & 0.287 & 0.758 \\
\hline
\end{tabular}

Distance to

pesticide

area

\begin{tabular}{lccccc}
\hline$R$ & .081 & .048 & .034 & -.085 & -.016 \\
$P$ & 0.534 & 0.709 & 0.790 & 0.514 & 0.903 \\
\hline
\end{tabular}

Table 7. Effects of age, gender, smoking, $\mathrm{PM}_{10^{\prime}} \mathrm{PM}_{2.5}$ values on pulmonary function (Linear regression analysis)

\begin{tabular}{|c|c|c|c|}
\hline Age & Unstandardized coefficient B & $\mathbf{T}$ & $\mathbf{P}$ \\
\hline FVC & -.562 & -3.785 & $<0.001$ \\
\hline FEV1 & -.590 & -3.808 & $<0.001$ \\
\hline FEV1/FVC & -.138 & -2.607 & 0.012 \\
\hline PEF & -.551 & -3.215 & 0.002 \\
\hline MMFR & -.850 & -3.929 & $<0.001$ \\
\hline \multicolumn{4}{|l|}{ Gender } \\
\hline FVC & -1.368 & -.304 & 0.762 \\
\hline FEV1 & 3.053 & .650 & 0.518 \\
\hline FEV1/FVC & -.586 & -.364 & 0.717 \\
\hline PEF & 19.694 & 3.830 & $<0.001$ \\
\hline MMFR & 15.778 & 2.446 & 0.017 \\
\hline \multicolumn{4}{|l|}{ Smoking } \\
\hline FVC & 4.173 & 1.165 & 0.249 \\
\hline FEV1 & 3.346 & 0.896 & 0.374 \\
\hline FEV1/FVC & 1.781 & 1.392 & 0.169 \\
\hline PEF & 3.101 & .730 & 0.468 \\
\hline MMFR & 5.775 & 1.093 & 0.279 \\
\hline \multicolumn{4}{|l|}{$\mathrm{PM}_{10}$} \\
\hline FVC & -2.108 & -5.230 & $<0.001$ \\
\hline FEV1 & -1.666 & -3.963 & $<0.001$ \\
\hline FEV1/FVC & .129 & .896 & 0.374 \\
\hline PEF & -1.605 & -3.502 & 0.001 \\
\hline MMFR & -1.375 & -2.401 & 0.020 \\
\hline
\end{tabular}

\begin{tabular}{lccl} 
PM $_{2.5}$ & & & \\
\hline FVC & -4.464 & -1.843 & 0.070 \\
FEV1 & -4.090 & -1.619 & 0.111 \\
FEV1/FVC & .023 & .027 & 0.979 \\
PEF & -4.577 & -1.644 & 0.105 \\
MMFR & -7.197 & -2.037 & 0.046
\end{tabular}

Table 8. Odds ratio values of $\mathrm{PM}_{2.5}$ and $\mathrm{PM}_{10}$ for symptoms

\begin{tabular}{|c|c|c|c|c|}
\hline & \multirow{2}{*}{$\operatorname{Exp}(B)$} & \multirow{2}{*}{$P$} & \multicolumn{2}{|c|}{ 95\% C.I. Exp (B) } \\
\hline & & & Lower & Upper \\
\hline \multicolumn{5}{|c|}{ Mouth-nose-throat burning } \\
\hline $\mathrm{PM}_{2.5}$ & 2.316 & 0.011 & 1.213 & 4.419 \\
\hline \multicolumn{5}{|c|}{ Eye burning } \\
\hline $\mathrm{PM}_{2.5}$ & 2.593 & 0.014 & 1.212 & 5.547 \\
\hline \multicolumn{5}{|c|}{ Wheezing } \\
\hline $\mathrm{PM}_{2.5}$ & 2.153 & 0.015 & 1.164 & 3.981 \\
\hline \multicolumn{5}{|c|}{ Chest tightness } \\
\hline $\mathrm{PM}_{2.5}$ & 2.211 & 0.012 & 1.190 & 4.108 \\
\hline $\mathrm{PM}_{10}$ & 1.123 & 0.047 & 1.002 & 1.259 \\
\hline
\end{tabular}

* Logistic regression analysis step 1 measures included age, gender, smoking, post-pesticide $\mathrm{PM}_{2.5}$ and $\mathrm{PM}_{10}$ variables. 
Health complaints of 66 subjects underwent both before and after evaluation increased and expected FVC and FEV values decreased significantly. The rates of FVC and FEV values lower than $80 \%$ were $21.2 \%$ and $22.7 \%$, respectively, before the pesticide period, and these rates increased to $39.4 \%$ and $42.4 \%$, respectively after pesticide period (Tab. 5).

The relationships between pulmonary function parameters and $\mathrm{PM}_{10}$ and $\mathrm{PM}_{2.5}$ levels, age, duration of smoking, except pesticide area distance from the treated place after pesticide administration, were statistically significant. There was a significant negative correlation between $\mathrm{PM}_{10}$ levels and FVC, $\mathrm{FEV}_{1}$, and PEF values, whereas there was a significant positive correlation between $\mathrm{PM}_{2.5}$ levels and FVC. A significant negative correlation was also observed between age and percent predicted FVC, FEV , FEV /FVC, PEF, and MMFR values, as well as between duration of smoking history and FVC, $\mathrm{FEV}_{1}$, and MMFR values (Tab. 6).

The presence was analyzed (by linear regression analysis) of independent effects of age, gender, cigarette use, and $\mathrm{PM}_{10}$ and $\mathrm{PM}_{2.5}$ levels over expected percentage $\mathrm{FVC}, \mathrm{FEV}_{1}, \mathrm{FEV}_{1} / \mathrm{FVC}$, $\mathrm{PEF}$, and MMFR values. When linear regression analysis was applied, age had significant negative and independent effects over all respiratory function values. Gender had an independent effect on PEF and MMFR (PEF and MMFR values were higher in males). There was a significant, independent, and negative effect of the $\mathrm{PM}_{10}$ variable overall values of the respiratory function, except for the $\mathrm{FEV}_{1} / \mathrm{FVC}$ ratio. The $\mathrm{PM}_{2.5}$ variant had significant, independent, and negative effects on MMFR values (Tab. 7).

Table 8 shows the respiratory symptoms observed after pesticide administration and the odds ratio for respiratory function tests (logistic regression analysis). With increased $\mathrm{PM}_{2.5}$ levels, the risk for burning in the mouth, nose, and throat increased 2.3-fold, and the risk increased 2.6-fold for burning symptoms in the eyes, 2.1-fold for wheezing, and 2.2-fold for chest tightness. With increased $\mathrm{PM}_{10}$ levels, chest tightness increased 1.1-fold.

\section{DISCUSSION}

In this study, a significant increase in both $\mathrm{PM}_{10}$ and $\mathrm{PM}_{2.5}$ levels was observed after emomectin benzoate and cyhalothrin application. The increase in $\mathrm{PM}_{10}$ levels exceeded the value of the World Health Organization's (WHO) 24-hour exposure limit of $50 \mu \mathrm{g} / \mathrm{m}^{3}$ by six-fold. The increase in $\mathrm{PM}_{2.5}$ levels was found to be below $25 \mu \mathrm{g} / \mathrm{m}^{3}$, which is the 24-hour exposure limit. The most commonly observed symptoms after pesticide application were burning in the eyes, shortness of breath, headache, cough, and itching. After pesticide application, all nose, throat, eye, and respiratory symptoms increased significantly in participants. In addition, the expected FVC and $\mathrm{FEV}_{1}$ percentage values decrease significantly.

There was a significant correlation between $\mathrm{PM}_{10}$ levels and FVC, $\mathrm{FEV}_{1}$, and PEF values, whereas there was a significant positive correlation between $\mathrm{PM}_{2.5}$ levels and $\mathrm{FVC}$ values. Although increased $\mathrm{PM}_{2.5}$ levels were correlated with a 2.3fold increase in risk of burning in the mouth, nose and throat; a 2.6-fold increase in risk of burning symptoms in the eyes; a 2.1-fold increase in risk of wheezing; and a 2.2fold increase in risk of chest tightness, the increase of $\mathrm{PM}_{10}$ levels were correlated only with a 1.1-fold increase in risk of chest tightness.
A significant increase in upper respiratory tract symptoms, including coughing, phlegm, shortness of breath, chest tightness and wheezing, was observed in adults due to increased $\mathrm{PM}_{10}$ and $\mathrm{PM}_{2.5}$ pollution after pesticide application [10]. The data on increased cough and phlegm due to pesticide application are increasing $[11,12]$. In a study conducted by Hoppin et al., 654 farmers with a history of pesticide exposure were found to have doctor-diagnosed chronic bronchitis. In this study, which identified 11 pesticides shown to increase the risk of chronic bronchitis, OR was observed as 1.5 with Heptachlor use. The risk of chronic bronchitis increased in the presence of predominantly high pesticide exposure, and in those with additional pesticide exposure due to nonfarming related activities [13].

In another study conducted with men and women, chronic bronchitis risk was found to be increased with the use of dichlorvos $(\mathrm{OR}=1.63)$, dichlorodiphenyltrichloroethane (DDT) $(\mathrm{OR}=1.67)$, cyanazine $(\mathrm{OR}=1.88)$, paraquat $(\mathrm{OR}=1.91)$, and methyl bromide $(\mathrm{OR}=1.82)$ [14]. In the same study, the use of pesticides for 120 days or more during a participant's lifetime increased the risk of chronic bronchitis. Wheezing has been observed in people who use commercial preparations of dichlorvosasan insecticide [15], and reports of pulmonary fibrosis and wheezing due to paraquat herbicide have also been made $[16,17]$. Employees in grain storage have reported wheezing and shortness of breath with methyl bromide acute exposure [18]. In the presented study, it was found that participants who had been exposed to pesticides due to living within one of four villages within $65 \mathrm{~km}^{2}$ of the application area, experienced burning of the mouth, nose, and throat (71.2\% of participants), sneezing (66.7\% of participants), burning (77.3\% of participants), coughing $(68.2 \%$ of participants), phlegm (65.2\% of participants), wheezing (62.1\% of participants), dyspnea (66.7\% of participants), and a feeling of tightness in the chest (62.1\% of participants).

With the increase of $\mathrm{PM}_{25}$ levels, after the administration of emomectin benzoate and cyhalothrin, the risk of burning in the mouth, nose, and throat, increased by 2.3 -fold, the risk of burning in the eyes increased by 2.6 -fold, the risk of wheezing increased by 2.1-fold, and the risk of chest tightness increased by 2.2-fold. However, increased $\mathrm{PM}_{10}$ levels were only correlated with a 1.1-fold increase in the risk of chest tightness.

Lopez et al. detected 40 different pesticides in the pesticidetreated agricultural areas in which they measured pesticides in the atmospheric $\mathrm{PM}_{10}$, indicating that $37 \%$ of them were insecticides. The same authors found Abamectin, an emomectin benzoate analog, in the context of atmospheric $\mathrm{PM}_{10}$. Both insecticides are macrolide compounds, which are in the organic dust group [19]. In the presented study, $\mathrm{PM}_{10}$ measurements exceeded the value of the World Health Organization's (WHO) 24-hour exposure limit of $50 \mu \mathrm{g} /$ $\mathrm{m}^{3}$ by six-fold (http://www.who.int/mediacentre/factsheets/ fs313/en/). Based on the literature, it can be argued that these particles contain emomectin benzoate and cyhalothrin. Short- and long-term exposures to $\mathrm{PM}_{10}$ and $\mathrm{PM}_{2.5}$ have been associated in numerous studies with asthma exacerbations, respiratory symptoms, and hospital admissions [10]. The presented study demonstrates an association between emomectin benzoate, cyhalothrin, and associated particulate contamination and a $62-77 \%$ increase in upper respiratory, lower respiratory, and eye symptoms. Although $\mathrm{PM}_{2.5}$ levels were below the WHO 24-hour exposure limit of $25 \mu \mathrm{g} / \mathrm{m}^{3}$, 
there was an increase in the atmosphere compared to the previous measurements, and there were finer particles. The long-term effects of PM were not assessed in the current study.

Studies investigating the effects of pesticides on pulmonary function tests have produced different results. There are publications showing that $\mathrm{FVC}, \mathrm{FEV}_{1}$, and $\mathrm{FEV}_{1} / \mathrm{FVC}$ values are decreased due to the use of organophosphate insecticide $[20,21,22]$. In farmers using an organophosphate spray, it was observed that the reduction in respiratory functions was compatible with a restrictive pattern and accompanied by a decrease in acetylcholinesterase levels in the blood. Employees involved in the production of carbamate and pyrethroid pesticides were also found to have significantly lower $\mathrm{FEV} / \mathrm{FVC}$ ratios and MMFR values in comparison to controls. However, significant decreases in respiratory function after employee exposure to pesticides were not reported. In a study conducted by Alif et al., pesticide and herbicide exposure increased fixed airway obstruction risk by 1.74- and 2.04-fold, respectively [23]. In the presented study, the rate of $\mathrm{FVC}$ and $\mathrm{FEV}_{1}$ under $80 \%$ of predicted values before pesticide exposure was higher compared to those after the pesticide use. The study group in this study had an average of 15 years of exposure to pesticides. The authors were not able to perform a reversibility test. The pre-pesticide $\mathrm{FEV}_{1} / \mathrm{FVC}$ ratio less than $70 \%$ was $5.3 \%$, and the post-pesticide level was $10.9 \%$. Although there was no control group in the presented study, it can be argued that long-term pesticide exposure may lead to both obstructive and restrictive dysfunctions. The rate of post-pesticide FVC and FEV individuals falling below $80 \%$ was above $40 \%$, whereas the $\mathrm{FEV}_{1} / \mathrm{FVC}$ ratio was below $75 \%$ in only one participant. This result showed that more restrictive respiratory dysfunction was observed with the combination of cyhalothrin and emomectin benzoate.

In the current study, one of the active pesticides, cyhalothrin, is an insecticide of the pyrethroid group, which causes tingling and burning of the face in humans, and the findings were observed for about five hours after exposure and lasting for days. This causes irritation of the nose and throat, dizziness, headache, nausea, loss of appetite, and fatigue. According to the classification of the World Health Organization's agrochemicals, cyhalothrinis in the medium dangerous agrochemical group (Group II) [24]. In a study in which lambda-cyhalothrin was used as an insecticide, coughing or sneezing and nose or throat irritation was observed in those staying at home [25].

This is the first study to compare respiratory function and general symptoms before and after open-air application of emomectin benzoate and cyhalothrin combination. Atomic $\mathrm{PM}_{10}$ and $\mathrm{PM}_{25}$ levels associated with emomectin benzoate ( $7 \mathrm{gr} / \mathrm{da})$ and cyhalothrin (4gr/da), which are used as pesticides in cotton cultivation, were shown to be increased. However, the measurement of pesticides in the particulate matter was not possible. Approximately $25 \%$ of the population in which pre-pesticide respiratory function was measured was also available for measurement after pesticide exposure. Despite this limitation, a significant decrease in the respiratory functions of the community, as well as other symptoms, were observed with the application of insecticides at the indicated doses under the given atmospheric temperature and humidity conditions. In future studies, it is important to monitor the pesticides used in open fields in cotton farming and to observe whether they are applied safely.

\section{CONCLUSIONS}

Because this study demonstrates the damage to respiratory health caused by pesticide use in agriculture, it should be expected that the use of pesticides may lead to the exploration of alternatives that would not be harmful to humans, other forms of life, and environmental health. The use of nontoxic pesticides and agricultural processes that lead to less particulate matter production during pesticide applications should be discussed, and measures to temporarily remove residents from the area during applications should be explored.

\section{Acknowledgments}

The authors extend their special thanks and appreciation to Prof. Peri Arbak and to the members of the Turkish Thoracic Society Environmental and Occupational Lung Disease team for their assistance at every point and enabled the success of the research.

\section{REFERENCES}

1. Arslan S, Aybek A. Particulate Matter Exposure in Agriculture, in Air Pollution. A Comprehensive Perspective. 2012; 3. http://dx.doi. org/10.5772/50084.

2. Gaffney P, Yu H. Computing agricultural PM10 fugitive dust emissions using process Specific emission rates and GIS.US EPA Annual Emission Inventory Conference 2003; 1-10. SanDiego.California. https://www3. epa.gov/ttnchie1/conference/ei12/fugdust/yu.pdf (last accessed on 2 October 2017).

3. Erisman JW, Bleeker A, Hensen A, et al. Agricultural air quality in Europe and the future perspectives. Atmospheric Environ. 2007; 42: 3209-3217.

4. Bogman P, Cornelis W, Rolle H, et al. Prediction of TSP and PM emissions from agricultural operations in Flanders, Belgium. Dust Conf 2007. Maastricht, Netherlands. Available at http://www.dustconf.org/ CLIENT/DUSTCONF/UPLOAD/S9/BOGMANB.PDF.

5. Socorro J, Durand A, Temime-Roussel B, et al. The persistence of pesticides in atmospheric particulate phase: An emerging air quality issue. Sci Rep. 2016; 6: 2267: 1-11.

6. Bossi R, Vorkamp K, Skov H. Concentrations of organochlorine pesticides, polybrominateddiphenyl ethers and perfluorinated compounds in the atmosphere of North Greeland. Environ. Pollut. 2016; 1-7. doi: 10.1016/j.envpol.2015.12.026.

7. Fenner K, Canonica S, Wackett L P, et al. Evaluating pesticide degradation in the environment: blind spots and emerging opportunities. Science 2013; 341: 752-758. doi:10.1126/science.1236281.

8. Nascimento MM, Rocha G O, Andrade J B. Pesticides in fine airborne particles: from a green analysis method to atmospheric characterization and risk assessment. Sci Rep. 2017; 7: 2267. DOI:10.1038/s41598-01702518-1.

9. Zuskin E, Mustajbegovic J, Schachter EN, et al. Respiratory function in pesticide workers. J Occup Environ Med. 2008; 50(11): 1299-1305.

10. World Health Organization. Health effects of particulate matter. Policy implications for countries in eastern Europe, Caucasus and central Asia. 2013, WHO Regional Office for Europe UN City, Marmorvej 51 DK- 2100 Copenhagen 0, Denmark.

11. Wilkins JR rd, Engelhardt HL, Rublaitus SM, et al. Prevalence of chronic respiratory symptoms among Ohio cash grain farmers. Am J Ind Med. 1999; 35: 150-163.

12. LeVan TD, Von Essen S, Romberger DJ, et al. Polymorphisms in the CD14 gene associated with pulmonary function in farmers. Am J Respir Crit Care Med. 2005; 171: 773-779.

13. Hoppin JA, Valcin M, Henneberger PK, et al. Pesticide use and chronic bronchitis among farmers in the agricultural health study. Amer J Ind Med. 2007; 50: 969-979.

14. Valcin M, Henneberger PK, Kullman GJ, et al. Chronic Bronchitis among Non-Smoking Farm Women in the Agricultural Health Study. J Occup Environ Med. 2007; 49(5): 574-583.

15. Hoppin JA, Umbach DM, London SJ, et al. Pesticides associated with wheeze among commercial pesticide applicators in the Agricultural Health Study. Am J Epidemiol. 2006; (163): 1129-1137. 
16. Kirkhorn SR, Garry VF. Agricultural lung diseases. Environ Health Perspect. 2000; 108 (4): 705- 712.

17. Hoppin JA, Umbach DM, London SJ, et al. Chemical predictors of wheeze among farmer pesticide applicators in the Agricultural Health Study. Am J Respir Crit Care Med. 2002; (165): 683-689.

18. Deschamps FJ, Turpin JC. Methyl bromide intoxication during grain store fumigation. Occup Med. (Lond) 1996; (46): 89-90.

19. Löpez A, Yusa V, Munoz A, et al. Risk assessment of airborne pesticides in a Mediterranean region of Spain. Science of the Total Environ. 2017; 574: $724-734$.

20. Peiris-John RJ, Ruberu DK, Wickremasinghe AR, et al. Low level exposure to organophosphate pesticides leads to restrictive lung dysfunction. Respir Med. 2005; 99 (10): 1319-1324.
21. Salameh P, Waked M, Baldi I, et al. Spirometric changes following the use of pesticides. East Mediterr. Health J. 2005; 11: 126-136.

22. Mekonnen Y, Agonafir T. Lung function and respiratory symptoms of pesticide sprayers in state farms of Ethiopia. Ethiop Med J. 2004; 42 (4): $261-266$

23. Alif SM, Dharmage SC, Benke G, et al. Occupational exposure to pesticides are associated with fixed air flow obstruction in middle-age. Thorax. 2017; 72 (11): 990-997.

24. World Health Organization Recommended Classification of Pesticides by Hazard and Guidelines to Classification 2009, WHO Press, World Health Organization, 20 Avenue Appia, 1211 Geneva 27, Switzerland.

25. Moretto A. Indoor spraying with the pyrethroid insecticide lambdacyhalothrin: Effects on spraymen and inhabitants of sprayed houses. Bull. World Health Organ. 1991; 69: 591-594. 